\title{
Effect of oil palm frond treated with ammonia on some carcass traits and meat chemical composition of Bali bulls - Indonesia
}

\author{
R.A. Muthalib and M. Afdal* \\ Department of Animal Production, Faculty of Animal Husbandry, University of Jambi, Jl. Raya Jambi - Ma. Bulian KM 15, \\ Mandalo Darat Jambi 36361, Indonesia, *correspondent author email: m.afdal@unja.ac.id
}

(Received October 21, 2017; Accepted December 2, 2017)

\begin{abstract}
The aim of this study was to evaluate the effect of oil palm frond treated with ammonia on the carcass weight (CW), rib eye muscle area (REMA) and some meat chemical composition in Bali bull in order to maximal optimization of this oil palm frond. Sixteen Bali bulls, weighing initially between 120 and $140 \mathrm{~kg}$, were randomly divided in to four groups of four animals each. The bulls were placed individually in wooden pens with cement flooring in an open bull barn. The bulls were each randomly assigned in a 60-day experiment. The four treatments included control diet $\left(\mathrm{P}_{0}\right)$, diet containing $25 \%, 50 \%$ and $75 \%$ of ammonia treated OPF for the $2^{\text {nd }}, 3^{\text {rd }}$ and $4^{\text {th }}$, respectively. Randomized Complete Block Design was followed with four treatments and four block of replications applied in this experiment. The results showed that there were no significantly different effect $(\mathrm{P}>0.05)$ at treatment on $\mathrm{CW}$, REMA and the meat chemical included water, crude protein (CP), ether extract (EE) and ash content. The findings reffered that, treatment $\mathrm{P}_{2}, 50$ of ammonia oil palm frond (OPF) tend to increase CW, REMA and the meat chemical content of Bali bulls.
\end{abstract}

Keywords: Oil palm frond, carcass, rib eye, meat, chemical composition, bull, Bali - Indonesia Available online at http://www.vetmedmosul.org/ijvs

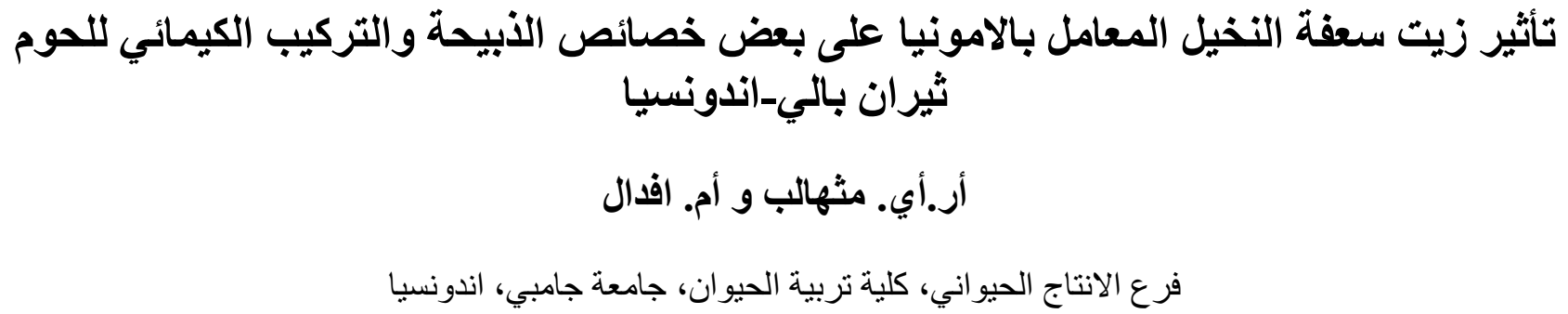

هدفت الدراسة لتقييم تأثير زيت سعف النخيل المعالج بالأمونيا على وزن الذبيحة (CW) ومساحة العضلة العينية الضلعية (REMA)

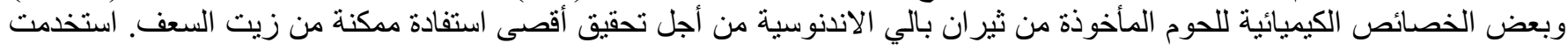

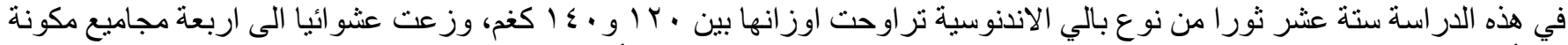

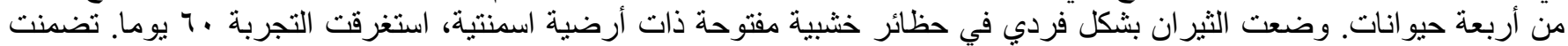

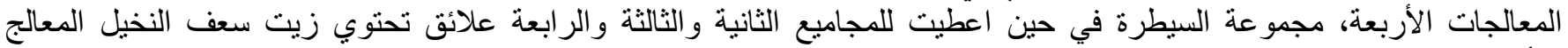

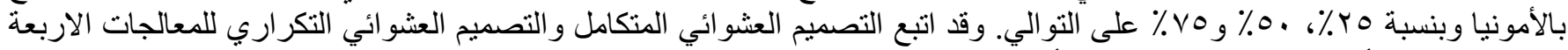

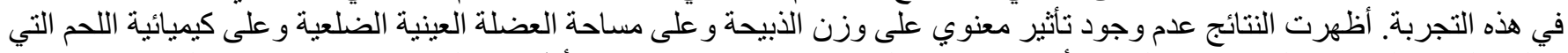

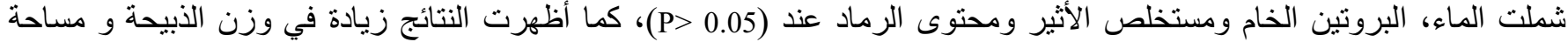

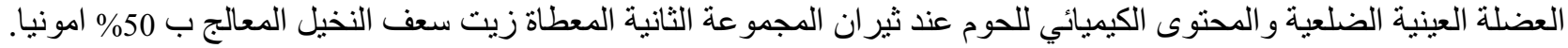

\section{Introduction}

Oil palm fronds (OPF) is a by-product from oil palm plantation that is available all the year especially in Indonesia and Malaysia or in other palm oil producing countries. It is a good potential source as an alternative feed 
for ruminants. Alimon and Bejo (1) reported that the chemical composition of OPF was high in crude fiber $(38,5 \%)$, Neutral Detergent Fibre $(78,7 \%)$ and Acid Detergent Fibre $(55,6 \%$ ), and low in crude protein of 4,7 $\%$. Mathius (2) added that the nutrient composition of OPF was $26.05 \%$ of dry matter, $5.10 \%$ of ash, $3.07 \%$ of crude protein, $50.94 \%$ of crude fibre, $1.07 \%$ of ether extract, $39.82 \%$ of nitrogen free extract and $4841 \mathrm{Kal} / \mathrm{g}$ GE. However OPF had been tried as based diet in beef and dairy productions in Malaysia (3). Oil palm petiole, the inner part of OPF, had been used as based feed in Bali cows to investigate its palatability (4) and its consumption and digestibility (5). One of the major constrains in utilizing OPF as feed in animal industry is low quality of nutrient, low digestibility and less palatability.

High content in crude fibre especially lignin in OPF causes low quality of its nutrient content. Therefore OPF is needed to be processed for example treated with ammonia which could improve the quality of OPF as a feed component. Sarnklong et al (6) reviewed that urea treatment method could be one of alternative to improve the quality of low nutritive value of rice straw, which is comparable to those of OPF. There are not many studies dealing with OPF effect on the carcass quality, rib eye muscle area and meat chemical composition.

Bali cow is important meat-producing animals in the tropic especially in Indonesia and meat has been increasingly consumed in that area because of its relatively high proportion in carcass weight. Carcass weight, rib eye muscle area and meat chemical compositions are the major components in determining the good quality and performance of meat.

The aim of this study was to evaluate the effect of ammonia-treated OPF in ration on the carcass quality, rib eye muscle area and meat chemical composition of Bali bull.

\section{Materials and methods}

\section{Animal and feed}

This experiment was conducted at Pilot Demonstration Place, Animal Husbandry Agency Sukadamai village, Tebo Regency, Jambi Province. The chemical analysis of meat was done at the Feed Analysis Laboratory, Faculty of Animal Husbandry, University of Jambi. Briefly, sixteen Bali local bulls, weighing initially between 120 and $140 \mathrm{~kg}$, were randomly divided in to four groups of four animals each. The bulls were placed individually in wooden pens with cement flooring in an open bull barn. After a threeweek adaptation period, the bulls were each randomly assigned to one of four dietary treatments in a 60-day experiment. The four treatments were (1) control diet $\left(\mathrm{P}_{0}\right)$, (2) balanced diet containing $25 \%$ of ammonia treated OPF $\left(\mathrm{P}_{1}\right)$, (3) balanced diet containing $50 \%$ of ammonia treated
OPF $\left(\mathrm{P}_{2}\right)$ and (4) balanced diet containing $75 \%$ of ammonia treated OPF $\left(\mathrm{P}_{3}\right)$ (see Table 1). Concentrate feed was manually mixed and consist of rice bran, tofu waste, salt and urea which meet the requirements of the animal feeding according to NRC (7). The feed analysis was carried out at the Laboratory of Feed Analysis, Faculty of Animal Husbandry, Jambi University, Indonesia, following conservational technique (8).

Table 1. The feed composition of experimental diet

\begin{tabular}{lcccc}
\hline \multirow{2}{*}{ Feed (DM \%) } & \multicolumn{4}{c}{ Treatment } \\
\cline { 2 - 5 } & $\mathrm{P}_{0}$ & $\mathrm{P}_{1}$ & $\mathrm{P}_{2}$ & $\mathrm{P}_{3}$ \\
\hline Concentrate & 25 & 25 & 25 & 25 \\
Field grass & 75 & 50 & 25 & 0 \\
Ammonia-treated OPF & 0 & 25 & 50 & 75 \\
\hline Total & 100 & 100 & 100 & 100 \\
\hline Nutrient content & & & & \\
Crude protein & 12.55 & 11.84 & 11.12 & 10.40 \\
Crude fibre & 21.86 & 21.94 & 21.62 & 21.38 \\
TDN & 60.4 & 62.6 & 64.8 & 67.0 \\
\hline
\end{tabular}

\section{Parameter measured}

Slaughter weight (SW) (kg), the animals were fasted for $24 \mathrm{~h}$ before slaughtering (9). Carcass weight $(\mathrm{kg}$ ) was done by weighing of animal after slaughtering as dressed carcass (9). Rib eye muscle area was determined by measuring the area of rib eye (longiisimus dorsi) on the scale of $12^{\text {nd }}$ and $13^{\text {rd }}$ classical vernia (10). Surface sliced rib eye muscle area was affixed with transparent plastic, then drawn with markers and then measured (11). Water, protein, ether extract and ash content of the examinal meat were analyzed according to (8).

\section{Experimental and statistical analysis}

Randomized Complete Block Design with four treatments and four blocks of replications was applied in this experiment. ANOVA followed by Duncan test were applied to analyze the mean of each parameter measured using SAS 9.2. All statistical tests were conducted at $95 \%$ confidence level using SAS (12).

\section{Results and discussions}

\section{Slaughtering weight}

The mean of SW of experimental bulls were between 154.00 and $160.75 \mathrm{~kg}$ (Table 2). The increase level of ammonia OPF in ration did not significantly $(\mathrm{P}>0.05)$ influence on the slaughtering weight of bulls. However it looks that $\mathrm{P}_{3}$, the use of $75 \%$ ammonia OPF in ration, tend to decrease SW. This increase might be due to animals which were relatively fed with the same ration composition (Table 1). Lawrie and Ledward (13) mentioned that the composition of nutrition generally affect growth rate as 
well as other factors such as regions which will affect the different tissues and various organs.

\section{Carcass weight and carcass weight percentage}

The means of carcass weight of experimental bulls were between 59.60 and $66.75 \mathrm{~kg}$ and carcass weight percentage of experimental bulls were between 36.30 and $41.94 \%$ (Table 2). There was not significant effect at $(\mathrm{P}>0.05)$ of a treatment on carcass weight and the percentage of carcass weight. However it looks that the use of $50 \%$ of ammonia OPF in ration provides the highest percentage of carcass weight. Fifty percent of the treatment ration with ammonia was the best which may be due to the improvement of feed conversion efficiency.

The results (Table 2) showed that there are no significant effects at $(\mathrm{P}>0.05)$ of treatment on the carcass and percentage of carcass weight of bulls. However, the treatment $\mathrm{P}_{2}, 50 \%$ of ammonia OPF manifested the highest percentage of carcass weight among treatments. Bowker et al. (14) stated that the percentage of carcass weight were influenced by several agent such as breed, age, feed intake, livestock conditions, sex, the contents of the digestive tract and the place where the animals were cultivated. Increasing of age and body weight will be followed by increasing carcass weight $(15,16)$, explained that factors affecting the percentage of carcass weight may be the digestive tract, vital organs and animal conditions which were subsequencetly influenced the development of the fat within abdominal cavity such as stomach, kidney, pelvic and heart.

\section{Rib eye muscle area}

Rib eye muscle area (REMA) is a factor influencing in estimating the amount of meat produced (Table 2). All treatments did not significantly affect at $(\mathrm{P}>0.05)$ on REMA. This might be due to relatively the same factors affecting on SW of bull in this experiment. The increase of REMA was liniar with SW. Romans and Ziegler (17) mentioned that REMA was related with the proportion of carcass tendon. Field and Schoonover (18) reported that REMA was influenced with animal weight preslaughter.

\section{Meat water content}

The water content of experimental meat was shown in Table 3. The water content of experimental meat was not significant difference at $(\mathrm{P}>0.05)$ among treatments. This might indicate that the four treatments did not influence water content of meat as the accumulation of fat in intramuscular fat or marbling was not optimal yet. In fact, the animal used in this experiment was in growing phase as the fat accumulation was not complete yet. The water content of meat was influenced with animal age (19), sex (20), fat content $(21,22)$. Minish dan Fox (23), added that the higher the meat fat content was, the lower the water content was. The average water content of meat was generally between 65 and $80 \%$ (24).

Table 2. The slaughter weight, carcass weight, and carcass percentage of experimental bulls

\begin{tabular}{lcccc}
\hline Treatment & Slaughtering weight $(\mathrm{kg})$ & Carcass weight $(\mathrm{kg})$ & Crcass percentage $(\%)$ & Rib eye muscle area $\left(\mathrm{cm}^{2}\right)$ \\
\hline $\mathrm{P}_{0}$ & $158.25 \pm 1.97$ & $59.60 \pm 2.92$ & $37.34 \pm 2.03$ & $49.25 \pm 3.12$ \\
$\mathrm{P}_{1}$ & $160.00 \pm 2.61$ & $66.75 \pm 1.88$ & $39.86 \pm 1.74$ & $49.75 \pm 2.98$ \\
$\mathrm{P}_{2}$ & $160.75 \pm 2.05$ & $64.52 \pm 2.39$ & $41.94 \pm 2.41$ & $51.00 \pm 2.74$ \\
$\mathrm{P}_{3}$ & $154.00 \pm 1.47$ & $61.25 \pm 2.56$ & $36.30 \pm 1.97$ & $47.25 \pm 2.30$ \\
\hline
\end{tabular}

Results are means \pm standard deviation; values mean of quadruplicate determinations.

Tabel 3. Meat chemical content of experimental cows

\begin{tabular}{lcccc}
\hline Meat chemical composition & \multicolumn{4}{c}{ Treatment } \\
\cline { 2 - 4 }$(\%)$ & $\mathrm{P}_{0}$ & $\mathrm{P}_{1}$ & $\mathrm{P}_{2}$ & $\mathrm{P}_{3}$ \\
\hline Water & $76.45 \pm 0.91$ & $75.25 \pm 0.77$ & $75.05 \pm 0.62$ & $74.86 \pm 1.43$ \\
Crude protein & $21.57 \pm 0.70$ & $21.73 \pm 0.77$ & $22.35 \pm 0.98$ & $21.82 \pm 0.90$ \\
Ether extract & $1.49 \pm 0.04$ & $1.56 \pm 0.09$ & $1.58 \pm 0.04$ & $1.51 \pm 0.07$ \\
Ash & $1.33 \pm 0.14$ & $1.27 \pm 0.10$ & $1.34 \pm 0.08$ & $1.32 \pm 0.15$ \\
\hline
\end{tabular}

Results are means \pm standard deviation; values mean of quadruplicate determinations.

\section{Meat protein content}

The crude protein content of meat of experimental bull was in between 21.57 to $22.35 \%$ (Table 3 ). There was not significant effect $(\mathrm{P}>.05)$ of treatment on meat crude protein content. Generally, the protein content of meat is relatively almost the same and possibly a very small different content in term of breed and SW. This difference of content of meat crude protein might be due to meat structure especially miofibril protein and bond tissue (25). The crude protein content is related to the water content as the hydrophilic property of meat protein is bonded to water molecule (26). Soeparno (27) clarified that the chemical 
composition of carcass could porpotionally change when one of other chemical content changed. The difference of water content, ash and fat in muscle could influence the crude protein content of meat.

\section{Meat fat content}

The crude fat or ether extract (EE) content of meat of experimental bulls was in between 1.49 to $1.58 \%$ (Table 3). There was not significant effect at $(\mathrm{P}>.05)$ of treatment on meat EE content. This result is in accordance with those of water, ash and crude protein content. Judge et al. (24) stated that EE depends on the carcass component having maximal growth at or latest growth after the growth of bone and muscle. The growth of intramuscular fat was at the end time after the growth of visceral fat and subcutanteous fat. Furthermore, EE content of meat varied and could be affected with breed, age, species, muscle parts and feed as well as the sex. Bulls used in this experiment were in the growth stage age so the fat development was not optimal yet.

\section{Ash content}

The ash content of experimental bulls is shown in Table 3. The mean of ash content was in between 1.27 and $1.34 \%$. It was not significantly different among four treatments. It was still in normal condition as the ash content of meat is relatively stable and possibly has a little variation. Forrest et al. (26) reported that ash content of the meat was closely related with water, protein content and free fat tissue. Free fat tissue is relatively rich in mineral content (28).

\section{Conclussion}

It was concluded that the treatment effect of ammonia into OPF tend to increase the carcass weight and the rib eye muscle area and also the chemical composition of meat was not relatively different among treatments.

\section{Refferences}

1. Alimon AR, dan Bejo MH. Feeding systems based on oil palm byproducts in Malaysia. $1^{\text {st }}$ Int. Symposium. On the integration of livestock to oil palm production. MASP/FAO and UPM, $25-27^{\text {th }}$ June 1995. Kuala Lumpur, Malaysia.

2. Mathius IW. Pengembangan sapi potong berbasis industri kelapa sawit. Pengembangan Inovasi Pertanian. 2008;1(2):206-224.

3. Zahari MW, Abu Hassan O, Wong HK, Liang JB. 2003. Utilization of Oil Palm Frond - Based Diets for Beef and Dairy Production in Malaysia. Asian-Aust J Anim Sci. 2003;16(4):625-634.

4. Afdal M, Syarif S, Kasim A. Effect of processing of palm oil petiole on palatability in Bali cows (Bos sondaecus) Proceedings of the British Society of Animal Science Annual Conference in Southport, UK, 30 March-1 April 2009;pp: 93

5. Afdal M, Darlis D, Syarif S, Kasim A, Alimon A R, Abdullah N. The effect of oil Palm Petiole in total mixed diet on the consumption and digestibility in Bali cows (Bos Sondaecus). The Proceedings of the
British Society of Animal Science constitute summaries of papers presented at the Society's Annual Conference in Belfast, UK, 12-14 April 2010;pp:209

6. Sarnklong C, Wcone J, Pellikaan W, Hendriks WH. Utilization of rice straw and different treatments to improve its feed value for ruminants: A review Asian-Aus J Anim Sci. 2010;23(5):680-692

7. NRC. Nutrient Requirements of Beef Cattle (7th Edition). National Academy Press, Washington, DC. 2000.

8. AOAC. Official Methods of Analyses, 17th ed Washington D C USA: Association of Official Analytical Chemists. 2000.

9. Bremner GJ. Meat Science Workshop. IPB - Australia Project. IPB, Bogor. 1989;pp:1 - 5.

10. Hilmia N, Noor RR, Sumantri C, Priyanto R, Gurnadi E. Relationship between Leptin Gene Diversity with Physical Quality of Local Beef In Ciamis. J Ilmu Ternak, 2015;2015:15(2):53-60

11. Muthalib RA. Carcass and Meat Characteristics of $F_{1}$ Cross Breed Among Bali Female Cattle and Four Sire Breed. J Indone Trop Anim Agricul. 2003;28(1):7-10.

12. SAS. SAS 9.2 TS Level 1MO. Cary NC USA: SAS Institute Inc. 2008.

13. Lawrie RA, Ledward DA. Lawrie's meat science $7^{\text {th }}$ Ed. Woodhead Publishing limited Cambridge England. 2006.

14. Bowker WAT, Dumsday RG, Frisch JE, Swan RA, Tulloh NM. A Course Manual in Beef Cattle Management and Economics. Australian Vice Chancellors Committee. Academy Press., Ltd. Brisbane. 1978.

15. Tulloh NM. Growth, Development, Body Composition, Breeding and management. In : A Course Manual in Beef Cattle management and Economics. WAT. Bowker, RG. Dumsday, JE. Frisch, RA. Swan dan NM. Tulloh ( Eds). Australian Vice-Chacellors' Committee. Academy Press Pty Ltd., Brisbane. 1978;pp:59 -91.

16. Cole HH. Introduction to Livestock Production. WH. Freeman and Company, San Francisco. 1966.

17. Romans JR, Ziegler PT.The Meat We Eat. $10^{\text {th }}$ Ed. The Interstate Printers \& Publishers, Inc., Danville Illinois. 1974.

18. Field RA. Schoonover CO. Equations for Comparing Longissimus Dorsi Areas in Bulls of Different Weights. J Anim Sci. 1967;26(4):709-712.

19. Tillman AD, Hartadi H, Reksohadiprodjo S, Prawirokusumo dan S, Lebdo-soekojo S. Ilmu Makanan Ternak Dasar. Gadjah Mada University Press., Yogyakarta. 1984.

20. Hamm R. The Walter Holding Capacity of Meat. In: Carcass Composition and Appraisal of Meat Animals. Selected Paper. D.E. Tribe (Ed.). CSIRO. Melbourne. 1964.

21. Cecchi LA, Huffman DL, Egbert WR, Jones WR Chemical and Physical Characteristics of Beef Chuck Muscle : Effect of Electrical Stimulation, Hot Boning and High Temperature Aging. J Food Sci. 1988;53:411.

22. Browning MA, Huffman DL, Egbert WR, Jungst SB. Physical and Compositional Characteristics of Beef Carcasses Selected for Leanness. J Food Sci. 1990;55:9.

23. Minish GL, Fox DG. Beef Production and Management. Reston Publishing Co., Inc. A Prentice-Hall Co., Reston Virginia. 1979.

24. Judge MD, Aberle ED, Forre JC, Hendrick HB, Merkel RA. Principles of Meat Science. $2^{\text {nd }}$ ed. Kendall / Hunt Publishing Co., Dubuque, IOWA. 1989.

25. Kramlich WE, Pearson AM, Tauber FW. Processed Meat. $2^{\text {nd }}$ ed. The Avi Publishing Co., Inc., West-port, Connecticut. 1973.

26. Forrest JC, Aberle ED, Hendrick HB, Jugde MD, Merkel RA. Principles of Meat Science. WH. Freeman and Co., San Fransisco. 1975.

27. Soeparno. Ilmu dan Teknologi. Fakultas Peternakan Universitas Gadjah Mada, Yogyakarta. 1997.

28. Dorsey KB, John C T, Steven B H, Dympna G. Greater Lean Tissue And Skeletal Muscle Mass Are Associated With Higher Bone Mineral Content In Children. Nutr Metab (Lond). 2010;7:41 doi:10.1186/1743-7075-7-41. 